\title{
Developmental control of promoter- specific factors responsible for the embryonic activation and inactivation of the sea urchin early histone $\mathrm{H} 3$ gene
}

\author{
Maurizio DiLiberto, Zhi-chun Lai, ${ }^{1}$ Hung Fei, and Geoffrey Childs ${ }^{2}$ \\ Department of Molecular Genetics, Albert Einstein College of Medicine, 1300 Morris Park Avenue, Bronx, New York 10461 \\ USA
}

We have begun an investigation of the molecular basis for the temporal embryonic expression of the early histone H3 gene of the sea urchin Strongylocentrotus purpuratus. Cloned constructs exhibit the proper temporal regulation following microinjection into one-cell zygotes of the related sea urchin species, Lytechinus pictus. Deletion analysis of the upstream promoter region of the $\mathrm{H} 3$ gene revealed several regions that are involved in both positive and negative control. DNase I footprinting, mobility shift, and methylation interference experiments reveal multiple sequence-specific DNA-binding proteins that interact with at least five distinct regions within 200 bp upstream of the RNA initiation site. Extracts prepared from staged embryos revealed that the ability of the factors to bind their target sequences was regulated. Proteins bound at four different sites were detected only at stages when the $\mathrm{H} 3$ gene was active transcriptionally. In addition, three different forms of a CCAAT-binding protein also are regulated temporally. The activity of these protein(s), however, correlates inversely with the transcriptional activity of the gene. The TATA box and CCAAT sequences are all that is required for expression of low levels of $\mathrm{H} 3$ transcripts with the proper temporal pattern. This approach should be useful in understanding the mechanisms used to regulate temporal patterns of gene expression during early embryogenesis.

[Key Words: Embryonic gene expression; histone H3 promoter; regulatory proteins; multiple CCAAT transcription factors]

Received November 9, 1988; revised version accepted April 25, 1989.

Sea urchins contain several differentially regulated families of histone genes that have provided a convenient model system to examine the molecular basis for temporal patterns of transcription during early embryogenesis. The early or embryonic histone genes are organized into 300-500 nearly identical tandem arrays, each of which encodes one copy of each of the five histone classes (for review, see Maxson et al. 1983). Each of the five genes contained within a tandem array constitutes an independent transcription unit. The ontogenic pattern of transcription of this gene family has been studied extensively using both steady-state and kinetic methods (Childs et al. 1979; Maxson and Wilt 1981, 1982; Mauron et al. 1982; Weinberg et al. 1983). Approximately $10^{6}$ mRNAs of each of the core histones and 80,000 molecules of early Hl mRNA (Mauron et al. 1982) accumulate after meiotic maturation. The levels of early mRNAs remain constant until new synthesis

${ }^{1}$ Present address: Department of Biochemistry, University of California, Berkeley, California 94720 USA.

${ }^{2}$ Corresponding author. increases at the 16-cell stage. The rate of synthesis of early histone mRNAs further increases by the early blastula stage $(9 \mathrm{hr}, \sim 128$ cells $)$ and then declines in 12-hr embryos $(\sim 200$ cells $)$ to about the synthetic level of 6-hr embryos (16-32 cells) (Maxson and Wilt 1981; Weinberg et al. 1983). This new synthesis results in a 10-fold increase in early histone mRNA, which constitutes $30-50 \%$ of total mRNA in the embryo. At the blastula stage these genes are shut off gradually and never again used in the life cycle of the animal (Kemler and Busslinger 1986; Lieber et al. 1986).

A second family of histone genes expressed during embryogenesis consists of the late- or adult-stage genes. There are $\sim 5-10$ dispersed copies of the core late histone genes and two copies of late $\mathrm{Hl}$ genes (Childs et al. 1981; Maxson et al. 1982; Kaumeyer et al. 1986; Kemler and Busslinger 1986; Knowles et al. 1987; Lai and Childs 1988). Transcripts encoding the late subtype histones also are detected at low levels in unfertilized eggs and transcribed at basal levels until the blastula stage of development when they are activated transcriptionally by about five- to sixfold (Knowles et al. 1984). We have 
shown that separate highly conserved sequences upstream of the coding sequences of late $\mathrm{H} 1$ genes constitutes a basal promoter and an element responsible for the transcriptional activation seen at the blastula stage of development (Lai et al. 1988). More recently, we demonstrated that the activator sequence referred to as USE IV, is a stage-specific enhancer that interacts with nuclear proteins both in vivo and in vitro (Lai et al., in press). The enhancer-binding protein is stored in eggs and is capable of binding its recognition sequence at all developmental stages tested including those where the enhancer is not active. The mobility of the factor stored in eggs, however, differs from the embryonic form, suggesting that post-transcriptional modification occurs following fertilization.

Recently, transcriptionally competent nuclear extracts derived from different embryonic stages of Drosophila embryos were shown to reproduce the temporal pattern of transcription faithfully from both alcohol dehydrogenase $(a d h)$ promoters (Heberlein et al. 1988) and the Ultrabithorax $(U b x)$ promoter (Biggin et al. 1988). In these examples, the transcription of the gene at a given stage of embryogenesis could be correlated with the presence of a positive-acting transcription factor that binds in a sequence-specific manner to the promoter of the gene. In the case of the distal adh promoter, the binding activity of the transcription factor Adf- 1 correlates with the transcriptional activity of the promoter. The $U b x$ promoter binds multiple sequence-specific transcription factors, some of which vary in activity during embryogenesis. This mechanism differs somewhat from the mechanism used by the late $\mathrm{Hl}$ stage-specific enhancer. In this case, the ability of the factor to bind its recognition sequence is regulated temporally either through the production of the factor or by posttranslational modification that modulates DNA binding.

The identification of cis-acting regulatory sequences controlling temporal and spatial gene expression during early sea urchin embryogenesis has been possible by the use of an elegant transient microinjection assay (McMahon et al. 1985; Colin 1986). Several genes including the actin CyIIIA (Flytzanis et al. 1987) and CyI (Katula et al. 1987) genes, the early histone H2a (Davidson et al. 1985) and H2b (Colin et al. 1988; Vitelli et al. 1988) genes, and the late histone H1 (Lai et al. 1988) and $\mathrm{H} 2 \mathrm{~b}$ (Colin et al. 1988) genes are each activated at the proper time following microinjection into eggs or fertilized one-cell zygotes. The proper spatial expression of microinjected CyIIIA actin DNA only in aboral ectoderm cells has been confirmed by in situ hybridization (Hough-Evans et al. 1987). This system has been used in conjunction with in vitro mutagenesis to identify regulatory sequences in the late $\mathrm{Hl}-\beta$ gene promoter and enhancer regions (Lai et al. 1988) and the two actin genes CyIIIA and CYI (Flytzanis et al. 1987; Katula et al. 1987). This approach to the identification of regions of genes regulating maximal and temporal expression can be combined with studies to identify and determine the ac- tivity of factors that interact with these sequences to determine the molecular mechanisms regulating ontogenic gene expression.

In this paper we studied the expression of the early $\mathrm{H} 3$ gene of the sea urchin, Strongylocentrotus purpuratus. We identified sequences that are essential for both positive and negative regulation of this gene as well as nuclear factors that interact with each of these essential elements. Nuclear extracts prepared from embryonic stages that are transcribing the early $\mathrm{H} 3$ genes contain proteins that are absent from extracts prepared from stages where the gene is repressed. Also, we detect changes in CCAAT-binding protein(s) during these early embryonic stages. Changes in the quantity or activity of these nuclear factors may be critical determinants of the temporal expression of this gene.

\section{Results \\ Temporal expression of microinjected early histone genes}

The temporal expression of early histone $\mathrm{H} 3$ and $\mathrm{H} 2 \mathrm{a}$ genes contained on different DNA constructs was examined following microinjection of fertilized one-cell zygotes. First, we compared both the level of expression and the temporal expression of the $\mathrm{H} 3$ and $\mathrm{H} 2 \mathrm{a}$ genes within the context of an entire 6.54-kb tandem array of five histone genes, with the expression using a smaller 1.8-kb EcoRI-HindIII fragment that contains only $\mathrm{H} 3$ and $\mathrm{H} 2 \mathrm{a}$ (Fig. 1).

Embryos were collected at 2-hr intervals and assayed for expression of microinjected $S$. purpuratus early H3 and $\mathrm{H} 2 \mathrm{a}$ transcripts as well as endogenous Lytechinus pictus early and late $\mathrm{H} 3$ transcripts. The transcripts from microinjected DNAs begin to accumulate at $6 \mathrm{hr}$ postfertilization and reach their peak in 10-12 hr embryos, precisely paralleling the activity of the endogenous early $\mathrm{H} 3$ genes in the same embryos. The microinjected genes also are inactivated transcriptionally with the endogenous early genes, and transcripts decline in 16-30 hr embryos. This decline represents accurate regulation, and is not caused by the loss of the injected DNA that continues to replicate and to accumulate (data not shown). The higher levels of endogenous $L$. pictus early H3 mRNA seen in 2-, 4-, and 6-hr embryos are derived from the stored pools, each with its $10^{6} \mathrm{ma}-$ ternal histone mRNAs (Mauron et al. 1982).

The microinjected embryos were normal in every respect and activated endogenous late $\mathrm{H} 3$ genes at the blastula stage when the early genes were repressed (Fig. 1). We could detect no differences in either the temporal pattern of expression or the level of expression when an entire 6.54-kb tandem array was used $\left(\mathrm{pCO}_{2}\right)$ or when a 1.8-kb fragment containing the $\mathrm{H} 3$ gene with $213 \mathrm{bp}$ of upstream DNA was included (Fig. 1A,B; data not shown). Thus, the $213 \mathrm{bp}$ of upstream DNA sequences represent the best candidates for the DNA elements required for both the activation and eventual repression of transcription of the early $\mathrm{H} 3$ gene. 

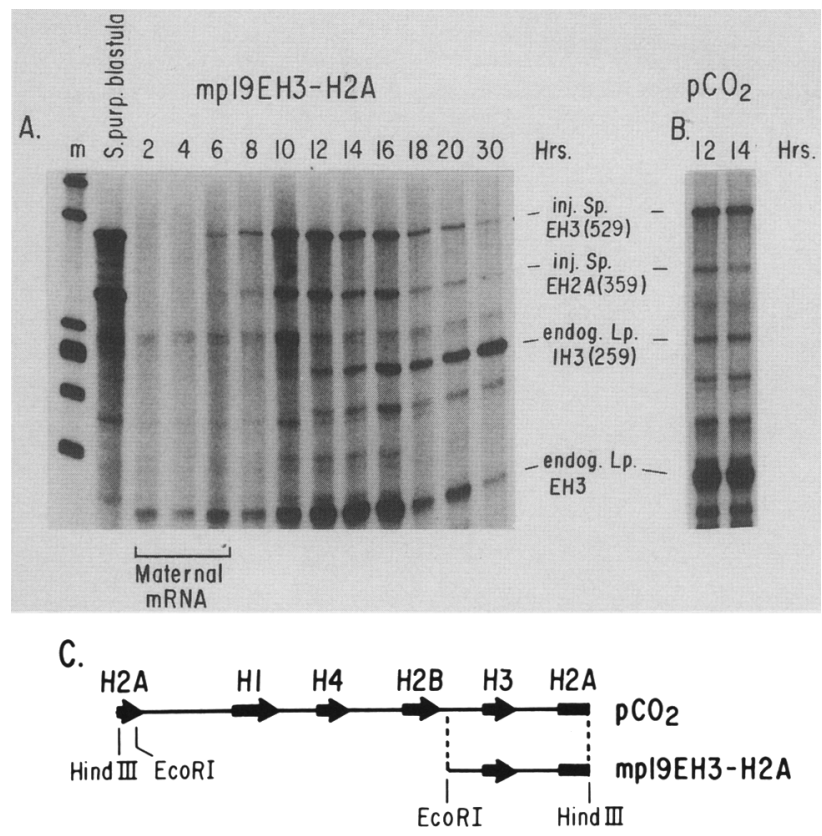

Figure 1. Ontogenic expression of microinjected early $\mathrm{H} 3$ and $\mathrm{H} 2$ a genes. Constructs $\mathrm{M} 13 \mathrm{mpl}$ EHH-H2a $(A)$ or $\mathrm{pCO}_{2}(B)$ were microinjected separately with about 2000 linearized DNA molecules as described in Materials and methods. Embryos were collected at 2-hr intervals following fertilization, and RNA was extracted for analysis of correctly initiated transcripts derived from the microinjected DNA. Each time point corresponding to the RNA derived from 20 injected embryos was probed with Sp6 transcripts complementary to $S$. purpuratus early $\mathrm{H} 3$ and $\mathrm{H} 2 \mathrm{a}$ and $L$. pictus late $\mathrm{H} 3$. Endogenous $L$. pictus early $\mathrm{H} 3$ crosshybridizes with the early $S$. purpuratus $\mathrm{H} 3$ probe to generate a smaller protected fragment. (Lane S. purp. blastula) Control using authentic $S$. purpuratus blastula stage RNA $(0.06 \mu \mathrm{g})$; (lane $M$ ) radiolabeled $\phi X 174$ HaeIII-digested DNA markers. Signals corresponding to $S$. purpuratus early $\mathrm{H} 3$ and $\mathrm{H} 2 \mathrm{a}$ as well as endogenous $L$. pictus early and late $\mathrm{H} 3$ are shown. $(C)$ Map of the two DNAs used in the microinjection experiment.

\section{Deletion analysis of the early $\mathrm{H} 3$ promoter}

We constructed a series of $5^{\prime}$ deletion mutants beginning at the EcoRI site at position - 213 upstream of the RNA initiation site. These constructs were linearized at the unique HindIII site, microinjected with late HI- $\beta$ DNA as a reporter gene, and the transcription levels were determined in 12-hr postfertilization blastula embryos (Fig. 2). Our results indicate that there are multiple cisacting regulatory sequences and that they act as both positive and negative regulators. Deletion of sequences between -213 and -149 decreases transcript accumulation to $30-40 \%$ of the level seen with either $\mathrm{pCO}_{2}$ or the -213 construct. Included in this region is a sequence CCATGT found in all early and late $\mathrm{H} 3$ genes examined (Kaumeyer et al. 1986), and an enhancer core sequence that could be a potential AP3 (Mitchell et al. 1987) or C/EBP (Johnson et al. 1987) transcription factor binding site. These regions correlate with two developmentally regulated DNase I hypersensitive sites (Bryan et al. 1983; Wu and Simpson 1985). Deletion to -133 removes an additional enhancer core sequence but has no additional effect on transcript accumulation. Deletion of sequences to -106 that include a pyrimidinerich region (on the coding strand) consistently restores transcript accumulation to levels at least as high as the wild-type -213 construct. This suggests the presence of a negative regulatory element in this interval of DNA. Removal of sequences between -106 and -86 results in a stepwise decrease in transcript abundance to $<10 \%$ the level of the -213 construct (longer exposures of Fig. 2B show low levels of transcripts|. This interval contains a purine-rich sequence (on the coding strand) and includes an additional DNase I hypersensitive site that correlates with the transcriptional activity of the gene (Wu and Simpson 1985). The remaining activity of the early $\mathrm{H} 3$ gene can be accounted for by a CCAAT sequence and the TATA box. Identical results were obtained with each construct whether the reporter gene used to normalize transcript levels was an equal amount of a coinjected late $\mathrm{H} 1-\beta$ gene or the intact early $\mathrm{H} 2 \mathrm{a}$ promoter contained on the same mp19EH3-EH2a (see Fig. 1C) DNA molecule. It is also interesting to observe that the late $\mathrm{Hl}$ promoter is much more efficient than the early $\mathrm{H} 3$ promoter, even in early blastula stage embryos before the USE IV enhancer allows maximal H1- $\beta$ promoter activity.

Several of the deletion constructs also were tested for correct temporal regulation following microinjection. Surprisingly, deletion to -78 still maintains the correct regulation. Transcripts accumulate between 6 and $12 \mathrm{hr}$ following fertilization and then decrease during the subsequent 12-hr interval (Fig. 3A). The difference between the -213 and -78 constructs is the level of early $\mathrm{H} 3$ transcripts that accumulate, confirming the data of the previous experiment. The embryos injected with the -78 construct all developed normally and accumulated late $\mathrm{H} 3 \mathrm{mRNAs}$ during the same developmental interval in which the early $\mathrm{H} 3$ and early $\mathrm{H} 2 \mathrm{a}$ transcripts declined (Fig. 3A). The -78 deletion contains only the TATA and CCAAT elements in addition to the coding sequence and may represent the minimal information required for proper regulation of this gene.

We ruled out the possibility that sequences within the coding region or $3^{\prime}$ to the gene regulate temporal expression by constructing fusion genes driven by the early $\mathrm{H} 3$ promoter. A construct containing the entire promoter region from -10 to -213 is expressed with the same temporal pattern as constructs containing the early $\mathrm{H} 3$ coding and $3^{\prime}$ sequences (Fig. $3 \mathrm{~B}$ ). When a fusion construct containing just the TATA box and CCAAT sequences $(-10$ to -85$)$ was injected at the same DNA concentration into the same batch of eggs, the signal was below the level of detection because this construct had only about $5 \%$ of the activity of the wild-type promoter. We injected the $-85 \mathrm{H} 3$-CAT construct into a different batch of eggs using higher concentrations of DNA; this resulted in embryos that exhibited delayed development. However, the construct is activated in 
DiLiberto et al.

Figure 2. Transcriptional activity of the microinjected $S$. purpuratus early $\mathrm{H} 3$ gene and $5^{\prime}$ deletion constructs. (A) Map of the upstream region of the $S$. purpuratus early $\mathrm{H} 3$ gene including the position of deletion end points, protein binding sites, and DNase I hypersensitive sites. (Solid boxes) Sites of protein binding (except TATA box where this was not tested); (hatched boxes) enhancer core consensus sequences for the mammalian transcription factors AP3 (Mitchell et al. 1987) and C/EBP (Johnson et al. 1987). (B) Deletion constructs (about 2000 molecules) were microinjected with equal quantities of late H1- $\beta$ DNA as a reporter gene. Microinjected embryos were allowed to develop to the blastula stage (12 hr), and RNA was prepared as described. Sp6 probes for early $\mathrm{H} 3$ and late $\mathrm{H} 1-\beta$ were combined and used to identify transcripts as described in Materials and methods and Lai et al. (1988). (Lane U1) Signal from uninjected $L$. pictus embryos; (lane S. purp. blastula) signal from authentic $S$. purpuratus blastula stage RNA $(0.03 \mu \mathrm{g})$; (lane $M$ ) radiolabeled $\phi X 174$ HaeIII-digested DNA. (C) Different autoradiographic exposures of the data in $B$ were scanned using an LKB Ultroscan Laser Densitometer and the signals from the $\mathrm{H} 3$ gene were normalized to the signal generated from the Hl- $\beta$ reporter gene. Then this data was plotted using the signal from the -213 construct as $100 \%$ activity. Identical data were generated when the reporter gene used was the early $\mathrm{H} 2 \mathrm{a}$ gene contained on the same plasmid as the $\mathrm{H} 3$ deletions.
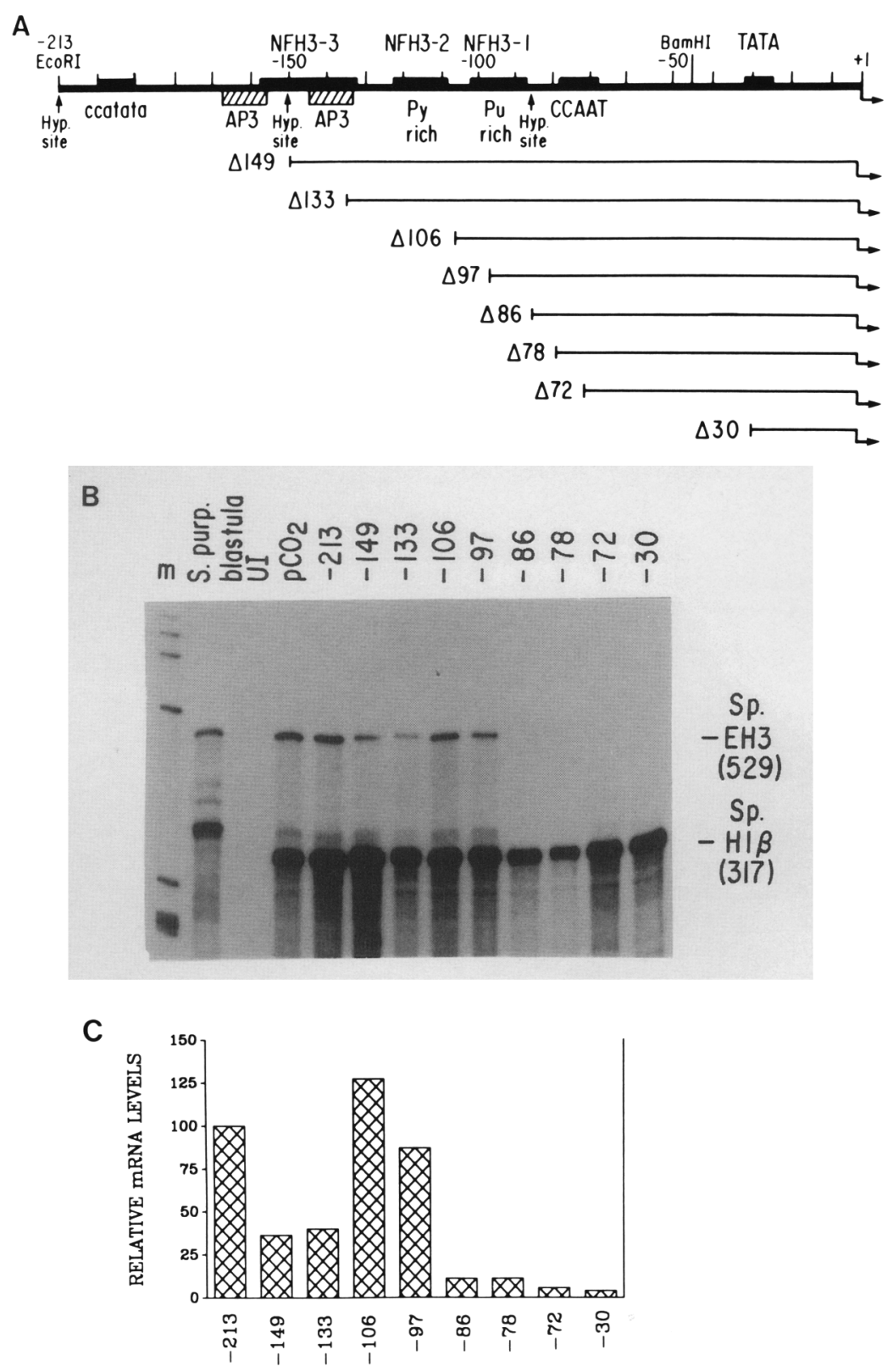

Temporal activity of nuclear DNA binding activities

12-hr embryos and repressed 2.2-fold in the 24-hr embyros (Fig. 3C). The residual expression of CAT enzymatic activity at $24 \mathrm{hr}$ is most likely the combined result of delayed development of these embryos, and, the fact that at high concentrations of injected DNA, the genes tend to remain active [presumably as a consequence of titrating out limiting quantities of a negative regulatory factor (H. Fei and Z.C. Lai, unpubl.)]. This experiment confirms that the TATA box and CCAAT sequences represent the minimal information necessary for temporal expression of the early $\mathrm{H} 3$ gene and suggests that a negative regulatory factor binds in this region of the promoter and represses the gene.
With the objective of correlating the activity of nuclear sequence-specific DNA-binding proteins with the transcriptional activity of the early $\mathrm{H} 3$ gene, we prepared nuclear extracts from 12-hr blastula and 24-hr late mesenchyme blastula-stage embryos. These time points represent stages when the $\mathrm{H} 3$ gene is active and inactive, respectively (Childs et al. 1979; Maxson and Wilt 1982; Weinberg et al. 1983). We tested these stage-specific extracts for the presence of such factors using DNase I footprinting (Galas and Schmitz 1978). Comparisons between extracts are based on using equivalent amounts of 

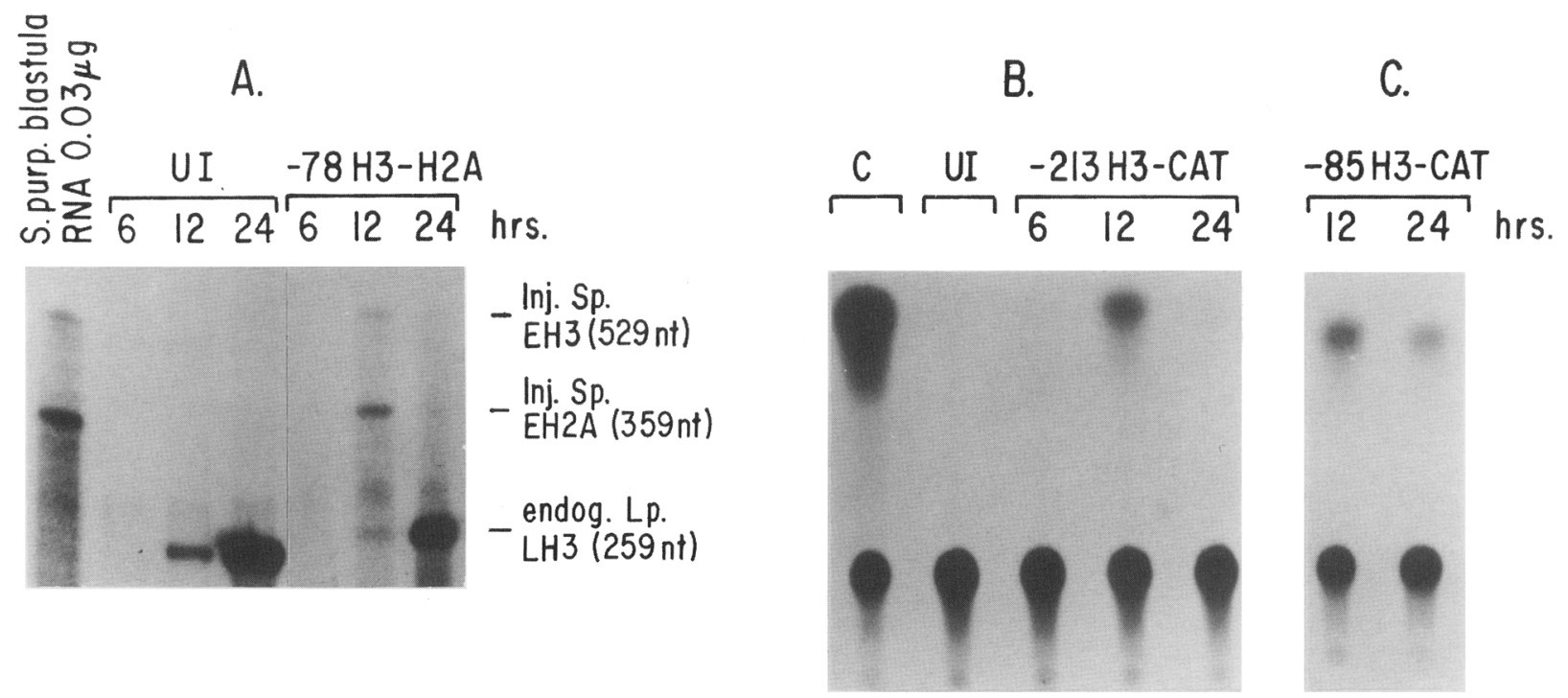

Figure 3. Ontogenic expression of early H3 constructs. $(A)$ DNA $(25 \mu \mathrm{g} / \mathrm{ml})$ of the -78 deletion construct was linearized before injection. About 2000 DNA molecules were delivered into each $L$. pictus one-cell zygote. RNAs were prepared from embryos collected at indicated time points after fertilization and hybridized to antisense riboprobes for exogenous $S$. purpuratus early $\mathrm{H} 3$ and $\mathrm{H} 2 \mathrm{a}$ transcripts and endogenous $L$. pictus late $\mathrm{H} 3$ transcripts. Protected RNAs (529 nucleotides, $S$. purpuratus early $\mathrm{H} 3 ; 359$ nucleotides, $S$. purpuratus early H2a; 259 nucleotides, L. pictus late $\mathrm{H} 3$ ) were resolved on $5 \%$ polyacrylamide $-7 \mathrm{M}$ urea gels. Total RNA (0.03 $\mu \mathrm{g}$ ) from $S$. purpuratus blastula stage embryos was used as a control. (Lane UI) Uninjected $L$. pictus embyros. Each reaction is from 20 injected or uninjected embryos. $(B)$ A fusion construct containing the early $\mathrm{H} 3$ promoter from -10 to -213 was injected at a concentration of $30 \mu \mathrm{g} / \mathrm{ml}$ as in $A$. Embryos were collected at the indicated times following fertilization and assayed for CAT enzymatic activity. Each time point represents the equivalent of 100 injected embryos assayed for $2 \mathrm{hr}$ at $37^{\circ} \mathrm{C}$. (Lane $C$ ) Signal generated by $1 / 50$ unit of authentic bacterial CAT enzyme. (C) A CAT fusion construct with H3 promoter sequences from - 10 to - 85 was microinjected at a DNA concentration of $100 \mu \mathrm{g} / \mathrm{ml}$. Embryos were collected at 12 and $24 \mathrm{hr}$ postfertilization and assayed for CAT enzymatic activity. Each time point represents the equivalent of 130 injected embryos assayed for $16 \mathrm{hr}$ at $37^{\circ} \mathrm{C}$.

protein in each binding reaction. Our data suggest that there are multiple factors that bind at five discrete locations between -46 and -213 , and that the activity of these factors varies during early embryogenesis (Fig. 4). The most obvious difference between the two staged extracts is the absence of four binding activities in extracts of 24-hr embryos. We refer to the activities that protect these four regions in 12-hr extracts as NFH3-1, NFH3-2, NFH3-3, and NFH3-4.

NFH3-1 protects a region of DNA from -89 to -99 . This includes a purine-rich sequence AAACAAAA conserved in the Psammechinus miliaris early $\mathrm{H} 3$ gene (Hentschel and Birnsteil 1981) and a region important for transcription (Fig. 2). NFH3-2 protects a region from -106 to -118 that includes a pyrimidine-rich sequence and the region implicated as a negative control site by our deletion analysis. NFH3-3 protects a region of DNA from -132 to -162 near the tandem enhancer core sequences. The binding region includes only the $3^{\prime}$-most enhancer core which is at the $3^{\prime}$ end of the NFH3-3 binding site rather than centered over it. Deletion of this region also results in lower transcript accumulation. NFH3-4 activity centers over two head-to-tail copies between position -184 and -202 of a sequence CCATGT conserved in early and late $\mathrm{H} 3$ genes (Kaumeyer et al. 1986). In addition to these factors that are present at higher quantities when the $\mathrm{H} 3$ gene is transcribed actively, the CCAAT-binding protein(s) appear to have lower activity in 12-hr extracts than in the 24-hr extracts. The CCAAT footprint extends from -66 to -85 using both extracts.

The specificity of three of these footprints was confirmed by competition experiments using oligonucleotides corresponding to the CCAAT, NFH3-2, and NFH3-3 binding sites (Fig. 5C). Excess quantities of individual oligomers eliminated the protected region corresponding to its binding site but not the other protected regions (Fig. 5A,B; data not shown). Occasionally, at high competitor concentrations, the CCAAT oligonucleotide competed the NFH3-3 footprint to a small degree. This was never seen using the mobility shift assay (see Fig. 7A). This experiment confirms that at least three distinct activities bind to the upstream region of the early $\mathrm{H} 3$ gene.

Mobility shift experiments (Fried and Cruthers 1981; Garner and Rezvin 1981) confirmed further the temporal regulation of three of the binding activities seen using DNase I footprinting. A 166-bp BamHI-EcoRI fragment spanning from position -46 to -212 was used in binding reactions with staged extracts from $6-\mathrm{hr}$ morula as well as the $12-\mathrm{hr}$ and $24-\mathrm{hr}$ extracts used in the footprint analysis (Fig. 6A). NFH3-3 forms the fastest migrating complex (see Fig. 7 for identification of the specificity and identity of each complex). This activity is present at high concentrations in 6-hr and 12-hr staged extracts and absent from the 24-hr extract. NFH3-2 
DiLiberto et al.

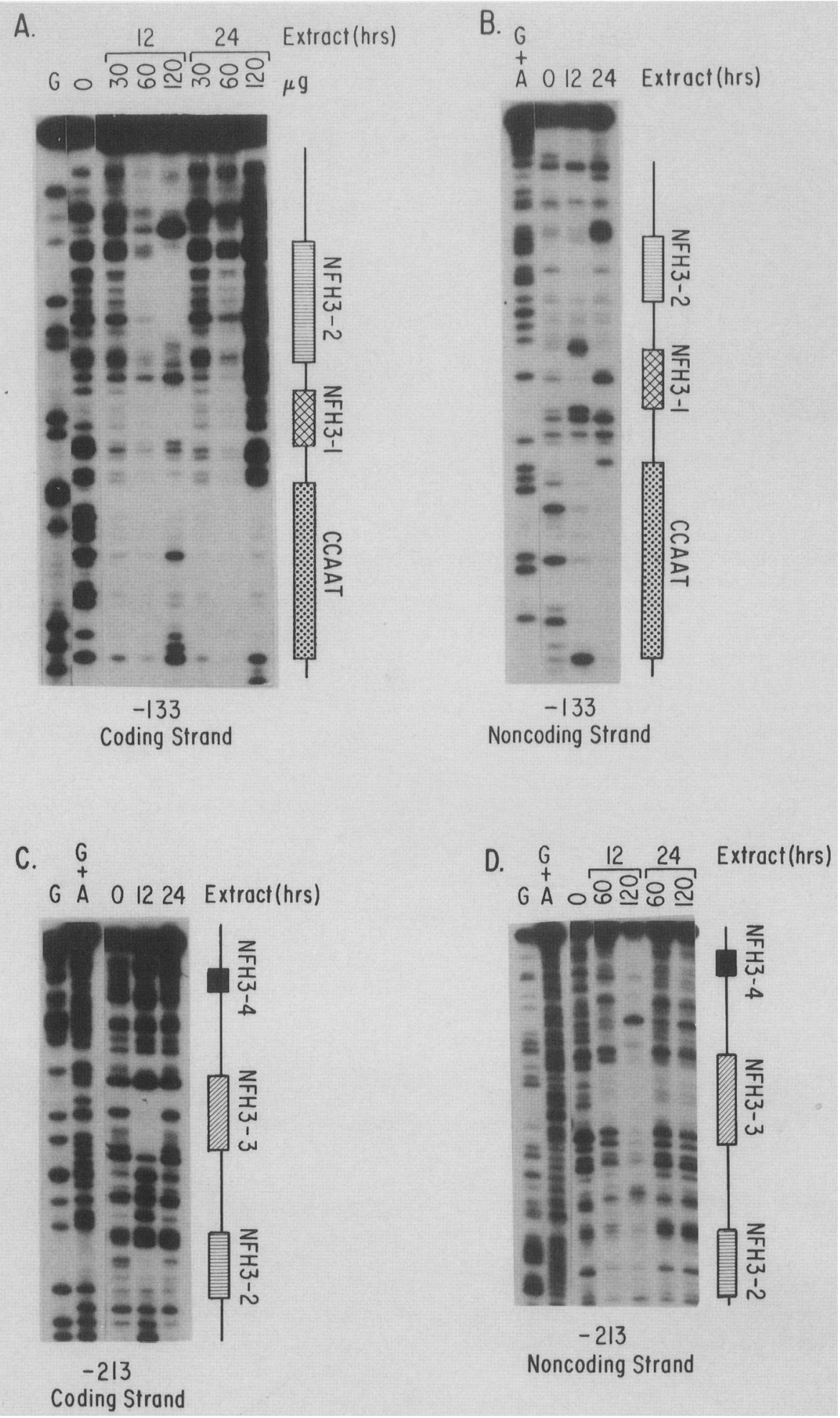

Figure 4. DNase I footprinting analysis of the sea urchin early $\mathrm{H} 3$ histone gene promoter with stage-specific nuclear extracts. The coding and noncoding strands of the early $\mathrm{H} 3$ promoter were $3^{\prime}$ - and $5^{\prime}$-end-labeled, respectively, at the BamHI site at position -46 , and digested at the EcoRI site either in the polylinker of the plasmid M13mp19EH3 $133(A, B)$ or at position -213 of the plasmid Sp6 $117(C, D)$. The probes were incubated with nuclear extracts from 12- to 24 -hr sea urchin embryos. After DNase I digestion, samples were electrophoresed on a denaturing $8 \%$ polyacrylamide gel. (Lanes $G$ and $G+A$ ) Maxam and Gilbert sequencing reactions were used for size markers. When protein concentration was varied, the amount of extracts ( $\mu \mathrm{g}$ of total protein) are indicated above the lanes. When only one protein concentration was used $(B, C), 60 \mu \mathrm{g}$ of extract was used. (Lane 0 ) Control reactions were on naked DNA. Boxes adjacent to the autoradiographs indicate the regions protected from DNase I digestion. 

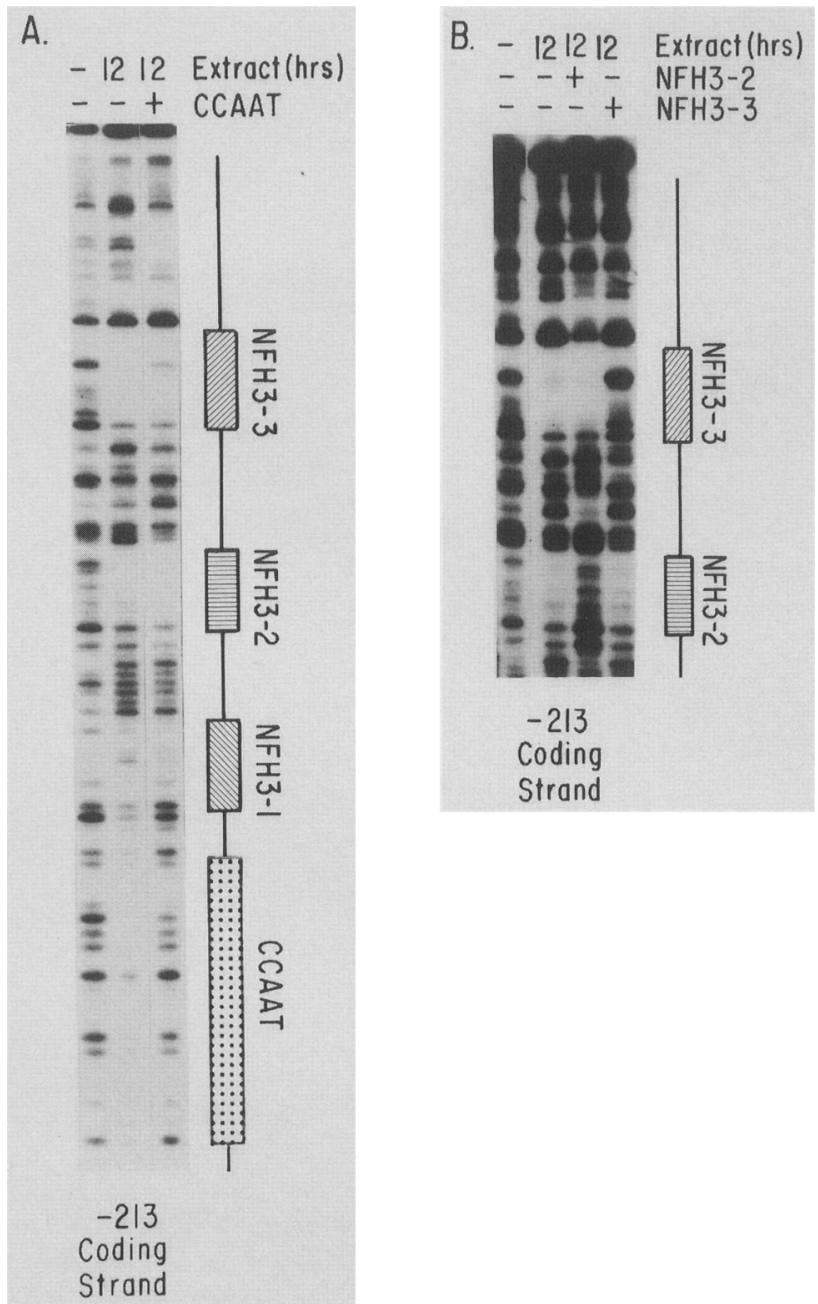

C.

\section{CCAat CaACCCGgtTGacCaAtCaAgagagctT}

\section{NFH3-2 GATCGCCAAGCCCCCTTCCCGTCACGCGCTAAACAA}

NFH3-3 GATCGACACATTTTATTGACTTTGCACATACGG

Figure 5. Footprint competition experiments. To characterize the specificity of the factors responsible for the footprints obtained with the 12 -hr extract and the early $\mathrm{H} 3$ gene promoter, the footprinting experiments were repeated with the coding strand probe in the absence (lane -) or presence (lane + ) of a 2000 -fold molar excess of double-stranded synthetic oligonucleotides containing the binding sites for CCAAT $(A)$, NFH3-2, and NFH3-3 $(B)$ nuclear factors. $|C|$ Sequence of the three oligonucleotides used in the competition experiments.

forms two complexes of intermediate mobility and the binding of this protein(s) has a requirement for the divalent cation $\mathrm{Mg}^{2+}$. The NFH3-2 complexes share the same temporal activity as the NFH3-3 activity. The CCAAT-binding activity is found at low levels in 6-hr extracts and increases in activity from 12 to $24 \mathrm{hr}$ postfertilization. The activity of this protein seems to be inhibited by $\mathrm{MgCl}_{2}$.
Because CCAAT and TATA sequences are all that are required for proper temporal expression, yet, CCAATbinding activity had an inverse relationship with the transcription state of the gene, we were curious to see whether there are changes in the properties of this activity during embryogenesis. The 28-bp CCAAT oligonucleotide allowed a higher resolution of complexes using the mobility shift assay (Fig. 6B). Distinct differences in CCAAT-binding activities could be detected in each of these staged extracts. The 6-hr extract contained small quantities of two complexes we refer to as CBP-1 and CBP-2. The activity of CBP- 1 decreases by $12 \mathrm{hr}$, but at the same time, the activity of CBP-2 increases and a new activity, CBP-3, appears. By $24 \mathrm{hr}, \mathrm{CBP}-2$ is gone and the activity of CBP-3 has increased. In mammals, the CCAAT transcription factors represent a complex group of heterotypic proteins that have been implicated to have roles in both positive (Chodosh et al. 1988; Santoro et al. 1988) and negative regulation (Flamant et al. 1987). In sea urchins, two different CCAAT-binding proteins interact with the sperm histone $\mathrm{H} 2 \mathrm{~b}$ promoter (Barberis et al. 1987). One is thought to act in a positive manner, whereas the other (CCAAT displacement protein) recognizes only the sperm H2b CCAAT box and is thought to regulate the sperm $\mathrm{H} 2 \mathrm{~b}$ gene negatively in embryos and tissues where it is not expressed. It is not clear yet whether the three CCAAT complexes we see represent different proteins or modifications of the same protein, but it is tempting to speculate that CBP-3 may be involved in repression of this embryonic gene. We do not see complexes corresponding to NFH3-1 and NFH3-4 under the conditions employed for the mobility shift assay.

The specificity of the mobility shift assays and the interactions between the DNA and the CCAAT protein, NFH3-2 and NFH3-3, were tested using competition studies (Fig. 7A). The band labeled CCAAT was identified by competition experiments using the CCAAT oligonucleotide. The addition of the CCAAT oligonucleotide eliminates the CCAAT band but not the band that corresponds to NFH3-3 (Fig. 7A, left three lanes). The NFH3-2 bands do not appear here because these three lanes were incubated in the absence of $\mathrm{MgCl}_{2}$ to maximize the CCAAT signal. Similarly, addition of NFH3-2 or NFH3-3 oligonucleotides eliminated the signal from the appropriately labeled complex.

Preparative binding reactions were performed to examine the protein-DNA contacts of the CCAAT protein and NFH3-3 using the methylation interference assay (Fig. 7B). The CCAAT-binding proteins from both 12-hr and 24-hr extracts gave very similar interference patterns. On the noncoding strand, the two guanosines at positions -75 and -76 within the CCAAT sequence, are protected as are the guanosines at positions -68 and -78 of the coding strand and the adenosines at positions $-70,-73$, and -74 on the coding strand (Fig. $7 B$ ). This pattern resembles the interactions between the mammalian CCAAT transcription factor CP-1 (Chodosh et al. 1988) and is identical in the noncoding strand with the sea urchin CCAAT-binding protein that interacts 


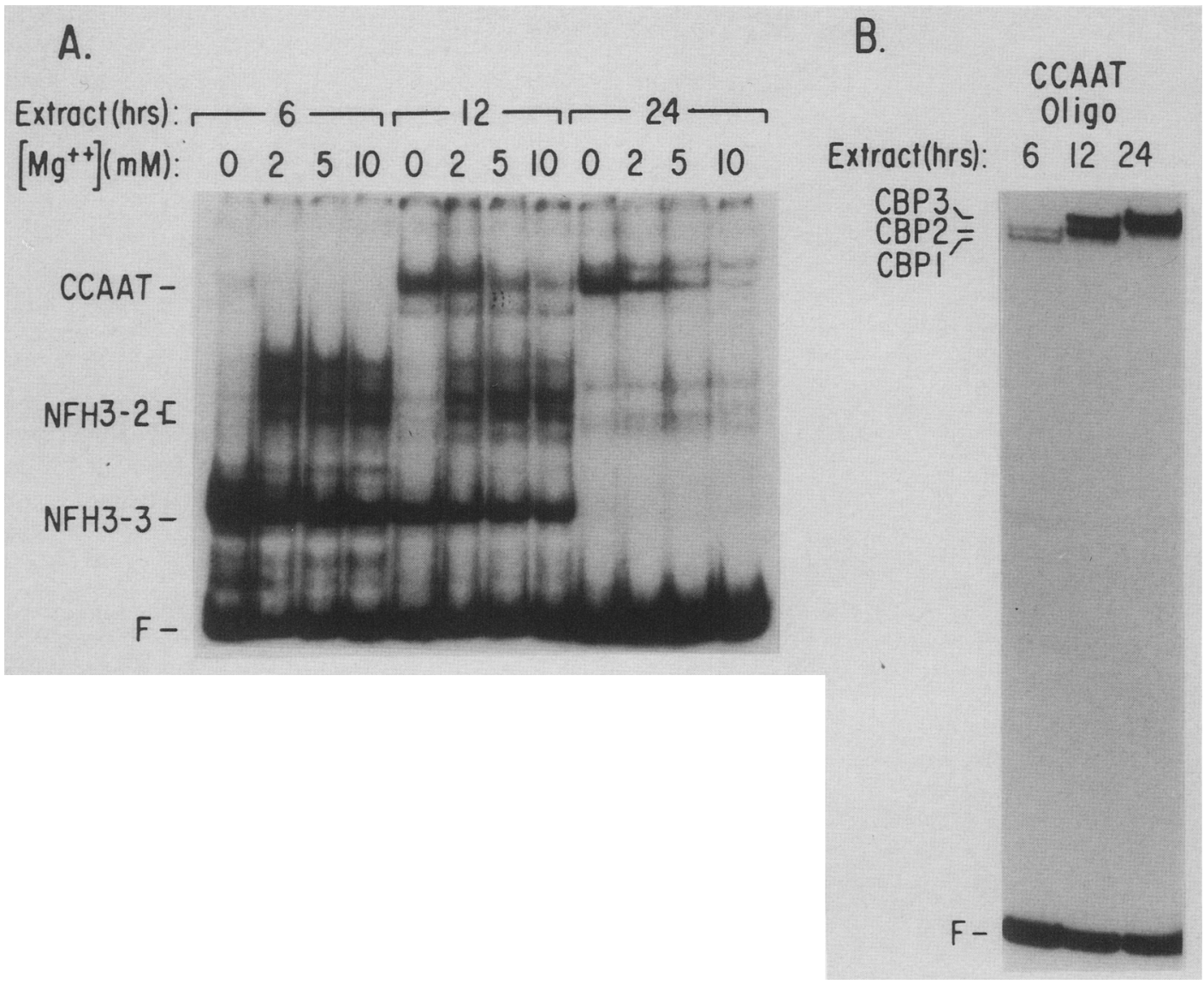

Figure 6. Gel retardation analysis of the early $\mathrm{H} 3$ histone gene DNA-binding proteins during sea urchin development. The assay was conducted using extracts from 6-, 12-, and 24-hr embryos in binding reactions with either the 3 '-end-labeled BamHI-EcoRI fragment $(A)$ or the $5^{\prime}$-end-labeled synthetic oligonucleotide containing the CCAAT sequence $(B)$. After incubation the complexes were separated by electrophoresis through a low-ionic strength $5 \%$ polyacrylamide gel. The $\mathrm{MgCl}_{2}$ concentrations used in the binding reactions are indicated $(A)$. The positions of specific DNA-protein complexes are indicated as CCAAT, CBP1-3 (CCAAT-binding proteins), NFH3-2, and NFH3-3 (nuclear factors), and that of the free DNA fragments as F.

with the sperm histone H2b gene (Barberis et al. 1987). In other experiments with the 12 -hr extract, the protection of the guanosine at -78 is more pronounced and we also see no difference when the CBP-2 and CPB-3 bands are excised and treated separately (W. Whyte, unpubl.). NFH3-3 protects a guanosine at position -145 of the coding strand, and a guanosine at position -143 and adenosines at positions -146 and -147 of the noncoding strand. Surprisingly, these residues are not within either of the core enhancer consensus binding sequences. Therefore, we believe that NFH3-3 is not a sea urchin equivalent of mammalian AP3 or C/EBP. The sequence of the $213 \mathrm{bp}$ of DNA upstream of the RNA initiation site (Sures et al. 1978) along with the interactions of proteins in this region is shown in Figure 8A.

\section{Discussion}

We have begun to study the cis-acting regulatory sequences in the early histone $\mathrm{H} 3$ gene and the activity of the nuclear factors interacting with these sequences with the aim of understanding the mechanisms that confer the temporal embryonic expression to this gene. We employed a transient expression system using microinjection of cloned DNA constructs to identify the DNA sequences necessary for promoter activity and correct temporal activity. A series of nuclear extracts derived from embryos that were either actively transcribing the $\mathrm{H} 3$ gene or where the gene was repressed were used to observe changes in the activity of factors that might be responsible for the regulation of the $\mathrm{H} 3$ gene. Our findings indicate that there are multiple sequences between -46 and -213 that act as both positive and negative controls of the early $\mathrm{H} 3$ gene. Biochemical analysis allowed us to detect the binding of at least one nuclear factor to each region of DNA shown to be required for the correct in vivo activity of the $\mathrm{H} 3$ gene.

Footprint analysis allowed us to identify factors that interact specifically with the CCAAT sequence between -66 and -85 . This activity is considerably lower in staged extracts from 12-hr blastula nuclei than 24-hr 


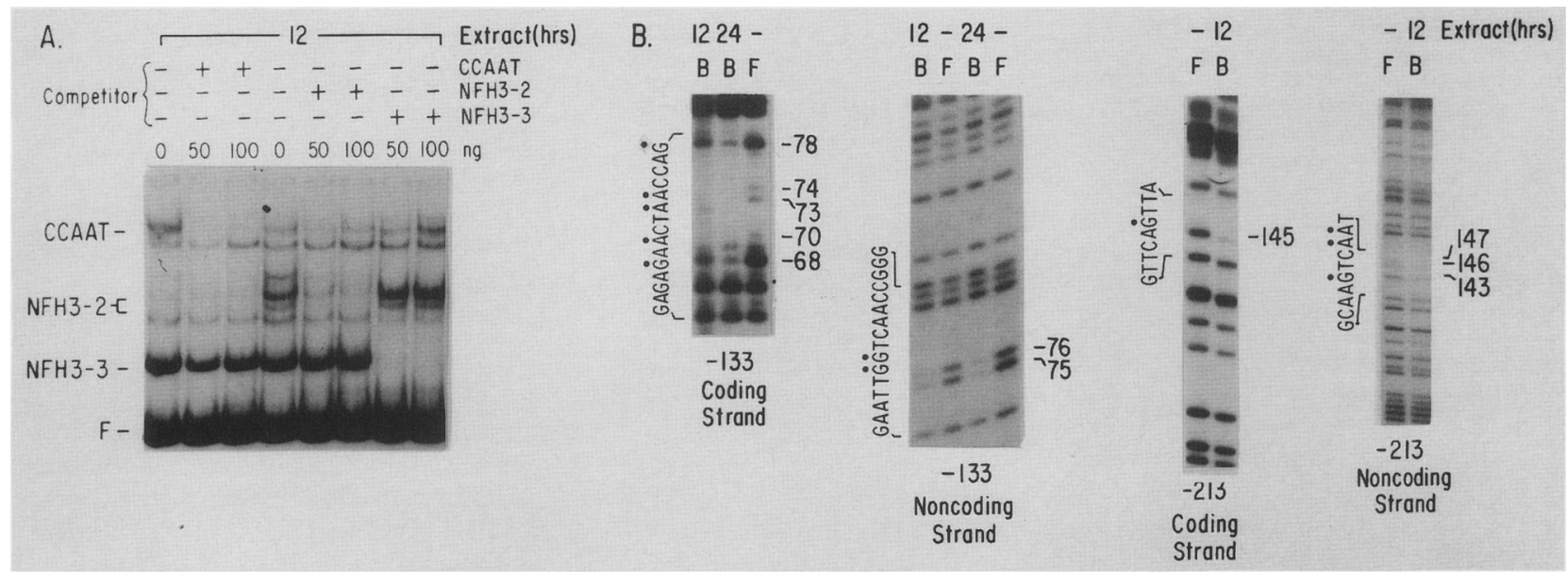

Figure 7. Identification of specific factors binding to the early $\mathrm{H} 3$ histone gene promoter. (A) Competition analysis of the early $\mathrm{H} 3$ specific DNA-binding proteins. The binding reactions were conducted in the absence (lane - ) or presence (lane + ) of a $500-$ or 1000-fold molar excess of the indicated double-stranded oligonucleotides (for their sequence, see Fig. 5). Symbols and abbreviations are as in Fig. 6. The first three samples were incubated in the absence of $\mathrm{MgCl}_{2}$, the others were incubated in the presence of $2 \mathrm{mM} \mathrm{MgCl}$. (B) Methylation interference analysis. The coding and noncoding strand probes used in the DNase I footprinting experiments were used for the methylation interference analysis of the CCAAT and the NFH3-3 complexes present in 12- and 24-hr nuclear extracts. The sequence of the two strands is shown to the left of the autoradiographs. (Lane $B$ ) Bound DNA fragment; (lane $F$ ) free DNA. The methylated $\mathrm{G}$ and $\mathrm{A}$ residues that interfere with the protein binding are indicated by their position relative to the transcription start site of the early histone $\mathrm{H} 3$ gene.

mesenchyme blastula nuclei. Our microinjection data, however, demonstrated that sequences to -78 are all that are required for correct ontogenic expression. This inverse activity in relationship to the transcription activity of the $\mathrm{H} 3$ gene led us to look for changes in CCAAT-binding proteins in these different extracts. Using a CCAAT-specific oligonucleotide, we were able to detect at least three different complexes using the mobility shift assay (Fig. 6B). There is low activity of the complexes CBP-1 and CBP-2 in an extract from 6-hr morula. By the early blastula stage, the activity of CBP-1 declines, that of CBP-2 increases, and a new complex CBP-3 appears. In the $24-\mathrm{hr}$ extract, only CBP-2 is present. From deletion analysis (Fig. 2; Z.C. Lai, unpubl.) we know that the TATA box and CCAAT sequences are sufficient for low-level activity of the $\mathrm{H} 3$ gene. Therefore, the CCAAT-binding protein is likely to act in a positive manner early in development and CBP-1 and CBP-2 are candidates for such positive-acting proteins. Now this can be tested using transcriptionally active in vitro systems derived from sea urchin embryos (Morris et al. 1986). It is, however, tempting to speculate that CBP-3 acts to repress the early $\mathrm{H} 3$ gene in late blastula stage embryos. The appearance of a negative regulator (CBP-3) in 12-hr blastula is consistent with measurements of the absolute rate of synthesis of early histone mRNAs (Maxson and Wilt 1981; Weinberg et al. 1983). Using independent methods, both groups determined that synthetic rates are about equal in 6-hr (16-32 cells) and $12-\mathrm{hr}$ ( 200 cell) embryos but the rate is $2-4$ times higher in 9-hr (128 cell) embryos. Thus, when we first see CBP-3 activity, the rate of synthesis of early H3 mRNA is declining from its peak rate at the early blas- tula stage. There is ample evidence accumulating that CCAAT-binding proteins are a heterogeneous set of proteins (Chodosh et al. 1988; Santoro et al. 1988) that can act as either positive or negative regulators. Unlike the sea urchin H2b CCAAT-binding and CCAAT-displacement proteins (Barberis et al. 1987), we were unable to detect obvious differences in the proteins using the methylation interference assay (Fig. 6B; W. Whyte, unpubl.). Further biochemical investigation of the biological activity of these proteins using in vitro transcription will be required to address this question properly.

Another nuclear protein, NFH3-1, binds to the sequences between -89 and -99 . Deletion of sequences between -106 and -97 and then -97 to -86 results in a stepwise 10 -fold decrease in in vivo promoter activity. By the use of DNase I footprinting, we could detect significant activity of NFH3-1 only in extracts from embryonic stages when the $\mathrm{H} 3$ gene was active (Fig. 3). We propose that temporal expression of this gene is determined by the combined activity of nuclear factors such as CBP-1 or CBP-2, NFH3-1, NFH3-3, and NFH3-4. A binding site for any one of these proteins could be sufficient for conferring patterns of temporal expression, but like so many other genes (for review, see McKnight and Tjian 1986), combinations of factors are employed and these factors together are required for maximal activity.

Deletion of sequences between -133 and -106 results in a reproducible increase in the relative transcription of microinjected $\mathrm{H} 3$ genes and a nuclear factor, NFH3-2, binds within this interval. It is not immediately obvious why a negative regulator would be active only at times when the $\mathrm{H} 3$ gene is transcribed. We can speculate that NFH3-2 prevents the overaccumulation 
A

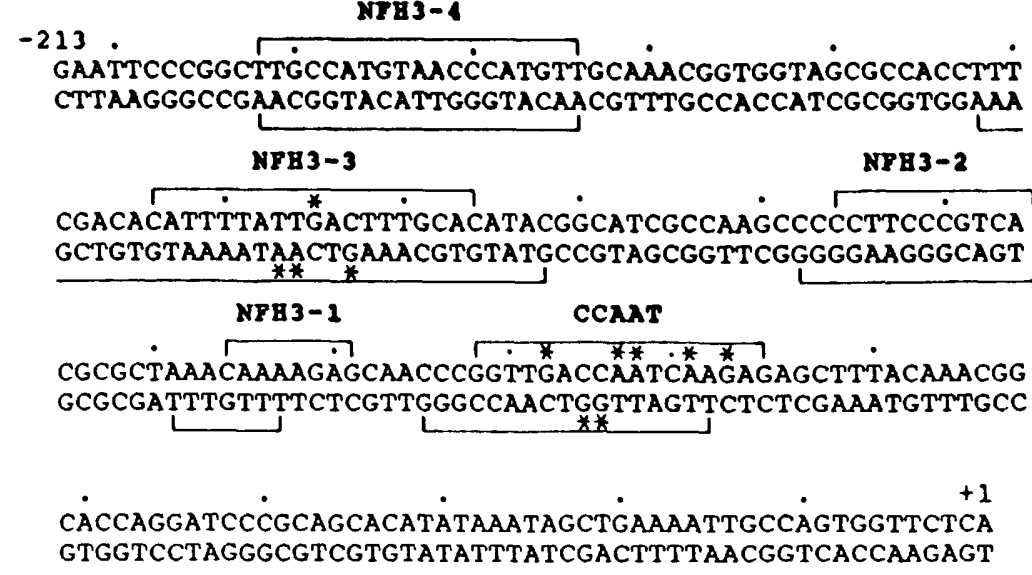

B
Early Cleavage Stage Embryos

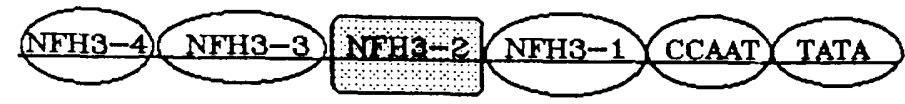

Late Blastula Stage Embryos
Figure 8. Summary of the DNA-protein interactions in the promoter of the early histone $\mathrm{H} 3$ gene. $(A)$ The transcription start site is indicated by +1 . Brackets above and below the DNA sequence mark the regions of the DNase I protection and an asterisk (*) marks the $G$ and $A$ residues at which methylation interferes with the binding of CCAAT and NFH3-3 nuclear transcription factors. $(B)$ A model for the ontogenic regulation of the early $\mathrm{H} 3$ gene. Factors present at the indicated embryonic stages are depicted by ovals for positive-acting proteins and by rectangles for negative-acting proteins. Early cleavage stage embryos are transcribing the early $\mathrm{H} 3$ gene while late blastula stage embryos are not. of early $\mathrm{H} 3 \mathrm{mRNA}$ relative to the other four histone mRNAs that must be regulated coordinately to form nucleosomes. It is still possible that the apparent negative effect of this element is an artifact of deletion analysis. Testing point mutations rather than deletions, moving the binding site to a heterologous gene, and in vitro transcription studies should clarify the role of NFH3-2 further.

We observe two ontogenically regulated footprints between -133 and -213 . Deletion of this region results in about a threefold decrease in relative transcription levels (Fig. 2), but the correct temporal expression is maintained. The 5 '-most footprint observed (NFH3-4) centers over two repeats of the CCAAT-like sequence, CCATGT, from position -184 to -202 . This sequence also is shared in all late $\mathrm{H} 3$ genes and may represent a common factor (Kaumeyer et al. 1986). The other footprint in this region corresponds to NFH3-3. Initially, we believed that NFH3-3 would be a sea urchin equivalent of the mammalian transcription factor AP3 (Mitchell et al. 1987) or C/EBP (Johnson et al. 1987) because of the two enhancer core sequences in the vicinity of the NFH3-3 binding site. The NFH3-3 footprint protects only the $3^{\prime}$-most enhancer core sequence and the methylation interference results show most of the critical contacts are outside this core consensus sequence (Fig. 7). Interestingly, part of the enhancer core CACATAC also is found in all late $\mathrm{H} 3$ genes and overlaps one of the CCAAT sequences of the $S$. purpuratus late $\mathrm{H} 3$ gene (Kaumeyer et al. 1986).
Our current model for the temporal embryonic expression of the early $\mathrm{H} 3$ gene is that the expression of the gene relies on the activity of multiple nuclear factors that temporally are expressed or activated. A diagram of the protein-DNA interactions at the $\mathrm{H} 3$ promoter when it is active and repressed is shown in Figure 8B. The egg is primed for synthesis of early histone transcripts, as new synthesis can be detected at the 2-cell stage (Childs et al. 1979). It is likely that the factors characterized in this work are stored in the egg. What happens at the 16cell stage and again at the early blastula stage to increase the rate of synthesis of this gene further awaits examination. It is possible that the mechanism involves the activation of more of the 300-500 tandem arrays. Alternatively, more subtle modulation of synthesis of all $300-500$ genes is possible.

We believe that any individual positive-acting factor, the DNA-binding activity of which is regulated during embryogenesis, could impart temporal expression to that gene. The redundancy imparted by multiple factors would insure that proper regulation is maintained. The mechanism used to regulate the activity of the factors is not clear. Failure to detect binding activity at a given developmental stage does not necessarily mean that the factor is absent. Post-translational modification may regulate the ability of a factor to bind to its target sequence. Additional negative control mechanisms also may be involved in the permanent inactivation of the gene. This model could be tested by creating artificial promoters that contain the H3 gene TATA-box sequence 
and one or multiple copies of binding sites for individual positive activators. Our model is similar in many respects to the mechanisms used by Drosophila embryos to impart temporal expression to the $U b x$ and $a d h$ distal promoters (Biggin and Tjian 1988; Heberlein and Tjian 1988|. Further characterization of the factors described in this report should clarify the mechanism used to regulate embryonic gene expression temporally.

\section{Materials and methods}

Microinjection of sea urchin one-cell zygotes

The procedure used was essentially that of McMahon et al. (1985) and Colin (1986), exactly as outlined in Lai et al. (1988).

\section{RNase protection assays}

Preparation of probes and subsequent analysis of protected fragments were performed essentially as described in Melton et al. (1984), with modifications as outlined in Lai et al. (1988).

\section{Construction of deletion mutants}

Deletions were constructed in M13 constructs (Messing and Vieira 1982) using the method of Dale et al. (1985). All deletion end points were confirmed by DNA sequence analysis (Sanger et al. 1977).

\section{Construction of early H3-CAT fusion constructs}

Two fragments containing sequences between position -10 and -213 and between -10 and -85 of the upstream region of the early $\mathrm{H} 3$ histone gene were amplified using polymerase chain reaction (PCR) (Saiki et al. 1988). Three oligonucleotide primers were synthesized on an Applied Biosystems 380B DNA synthesizer. One primer (A), 5'-GAAGCTTTGGCAATTTTCAGCT-3', was complementary to the $(-\mid$ strand from position -10 to -24 . The two other primers were complementary to the $(+)$ strand from position -71 to $-85(B), 5^{\prime}$-GAAGCTTCCCGGTGACCAATC- $3^{\prime} ;$ and -199 to -213 (C), 5'GAAGCTTGAATTCCCGGCTTGC-3', respectively. Aliquots of $1 \mu \mathrm{g}$ of each of the primers $(\mathrm{A}+\mathrm{B}$ or $\mathrm{A}+\mathrm{C})$ were incubated with $5 \mathrm{ng}$ of pSp6-117 plasmid DNA used as template in the presence of Taq DNA polymerase following the GENE AMP kit protocol (Perkin Elmer Cetus). Following amplification, DNA ends were repaired using the Klenow fragment of DNA polymerase (Maniatis et al. 1982), phenol-chloroform extracted, and concentrated by ethanol precipitation. The two fragments were subcloned into the HindIII site of pIBI-CAT that was blunt-ended by filling in with the Klenow fragment of DNA polymerase. pIBI-CAT is a promoterless CAT vector, prepared by subcloning the BamHI-HindIII fragment of pSV2CAT (Gorman et al. 1982) into the pIBI31 vector.

\section{Chloramphenicol acetyltransferase assays}

Injected embryos at various stages of development were collected with $\sim 1500$ uninjected embryos of the same age as the carrier. Embryos were washed in $0.25 \mathrm{M}$ Tris- $\mathrm{HCl}(\mathrm{pH} 7.8$ ) and resuspended in $100 \mu \mathrm{l}$ of the same buffer. Following three consecutive freeze-thaw cycles (McMahon et al. 1984), CAT enzyme activity was assayed as described by Gorman et al. (1982). Purchased authentic bacterial CAT enzyme (Pharmacia) was used as a positive control.

\section{Preparation of nuclear extracts}

Crude nuclear extracts were prepared essentially by the method of Morris et al. (1986) to make transcriptionally competent extracts. S. purpuratus embryos were grown at $16^{\circ} \mathrm{C}$ to the desired stage of development and then collected by low-speed centrifugation. The early stage embryos were fertilized in the presence of $1 \mathrm{~mm}$ PABA (para-aminobenzoic acid) to prevent the fertilization membrane from hardening and to obtain a better yield of intact nuclei. All of the subsequent steps were performed at $4^{\circ} \mathrm{C}$. Embryos were washed twice with $0.55 \mathrm{M} \mathrm{KCl}$, and once with buffer I $[0.25 \mathrm{M}$ sucrose, $0.01 \mathrm{M}$ Tris $(\mathrm{pH} 7.5], 0.1 \mathrm{~mm}$ EDTA]. Then they were resuspended in 5-10 volumes of buffer II $[0.32 \mathrm{M}$ sucrose, $0.01 \mathrm{M}$ Tris ( $\mathrm{pH} 8.0), 5 \mathrm{~mm} \mathrm{MgCl}_{2}, 1 \mathrm{~mm}$ EDTA, $1 \mathrm{mM}$ spermidine, $1 \mathrm{~mm}$ dithiotreitol (DTT), $0.1 \mathrm{~mm}$ [phenylmethylsulfonyl fluoride (PMSF)] and homogenized with 10-20 strokes in a Dounce homogenizer. Nuclei were pelleted by low-speed centrifugation and were resuspended in buffer II. The concentration of sucrose was increased to $1.4 \mathrm{M}$ by the addition of 2 volumes of $2 \mathrm{M}$ sucrose in buffer II. The nuclei from 6-hr embryos (morula) and from 12- to 24-hr embryos (early-late blastula) were layered over $1.8 \mathrm{M}$ and $2 \mathrm{M}$ sucrose in buffer II, respectively, and were centrifuged at $19,000 \mathrm{rpm}$ for $45 \mathrm{~min}$ in a SW-27 rotor. The nuclear pellets were resuspended by homogenization in 10 volumes of buffer III $[0.1 \mathrm{M} \mathrm{KCl}, 20 \mathrm{mM}$ HEPES (pH 7.9), $1 \mathrm{mM}$ DTT, $0.1 \mathrm{mM}$ EDTA, $0.1 \mathrm{mM}$ PMSF] extracted with $0.4 \mathrm{M}\left\langle\mathrm{NH}_{4}\right\rangle_{2} \mathrm{SO}_{4}$ for $30 \mathrm{~min}$, and centrifuged at $35,000 \mathrm{rpm}$ for $60 \mathrm{~min}$ in a $60 \mathrm{Ti}$ rotor to pellet the chromatin. The supernatant was collected and the proteins were precipitated by the addition of 0.25 grams of $\left(\mathrm{NH}_{4}\right)_{2} \mathrm{SO}_{4}$ per milliliter of supernatant. The precipitated proteins were pelleted by centrifugation at $35,000 \mathrm{rpm}$ for $15 \mathrm{~min}$ in the $60 \mathrm{Ti}$ rotor. The pellets were resuspended in $1-2 \mathrm{ml}$ of buffer III containing $20 \%$ glycerol and dialyzed against the same buffer until the conductivity of the extract reached $0.1-0.15 \mathrm{M} \mathrm{KCl}$. The nuclear extract was cleared by centrifugation at $10,000 \mathrm{rpm}$ for $15 \mathrm{~min}$ in a Sorvall SS34 rotor and was stored in aliquots in liquid nitrogen. The protein concentration of the extracts was $6-12 \mathrm{mg} / \mathrm{ml}$ as determined by using the Bio-Rad protein assay kit.

\section{Probes for DNase I footprinting and gel retardation assay}

Fragments containing the $5^{\prime}$-upstream region of the early $\mathrm{H} 3$ promoter were obtained from plasmids Sp6-117 $(-213)$ and M13mp19EH3 $133(-133)$ by digesting with BamHI at position -46 and end-labeling with either Klenow DNA polymerase and $\left[\alpha^{-32} \mathrm{P}\right] \mathrm{ATP}$ or $\mathrm{T}_{4}$ polynucleotide kinase and [ $\gamma-32$ P]ATP (Maniatis et al. 1982). Then the DNAs were digested with $E c o R I$ and the $166 \mathrm{bp}$ (or $102 \mathrm{bp}$ ) fragment was purified by polyacrylamide gel electrophoresis.

\section{Purification and annealing of synthetic oligonucleotides}

Oligonucleotides were synthesized on an Applied Biosystems Automated DNA Synthesizer and desalted on a Sephadex G-50 column using $0.01 \mathrm{~m} \mathrm{TEAB}$ (triethylamine bicarbonate) as a mobile phase. Samples were lyophilyzed to remove the solvent, resuspended in $98 \%$ formamide, and purified on a $12 \%$ polyacrylamide $-7 \mathrm{M}$ urea gel. The DNA was visualized under shortwave UV light over a fluorescent silica gel TLC plate. The bands containing the DNA were excised from the gel and eluted using the crush and soak procedure. The DNA was concentrated by sec-butanol extraction and desalted on a Sephadex G-50 column. Equimolar quantities of complementary oligonucleotides were combined in $0.1 \mathrm{M} \mathrm{NaCl}, 0.01 \mathrm{M}$ Tris (pH 7.8), 
and $1 \mathrm{mM}$ EDTA; denatured at $90^{\circ} \mathrm{C}$ for $3 \mathrm{~min}$; and allowed to anneal by incubating at $56^{\circ} \mathrm{C}$ for $1-2 \mathrm{hr}$. The annealed strands then were ethanol-precipitated and resuspended in TE buffer [0.01 M Tris (pH 7.5), 1 mM EDTA].

\section{DNase I footprinting}

DNA probes 5 '- or 3 '-end-labeled $(5000 \mathrm{cpm})$ were mixed with $30-120 \mu \mathrm{g}$ of nuclear extracts in $25 \mu \mathrm{l}$ of binding buffer $[0.1 \mathrm{M}$ Tris (pH 7.5), $0.08 \mathrm{M} \mathrm{NaCl}, 4 \%$ glycerol, $0.01 \mathrm{M}$ 2-mercaptoethanol, $1 \mathrm{~mm}$ EDTA] that contained $1 \mu \mathrm{g}$ of poly[d(I-C)], and incubated on ice for $30 \mathrm{~min}$. Samples were brought to $1.5 \mathrm{mM} \mathrm{MgCl}$ and digested with 5-10 $\mu \mathrm{g}$ of DNase I for $90 \mathrm{sec}$ on ice (Barberis et al. 1987). Reactions were terminated by the addition of $0.6 \mathrm{M}$ $\mathrm{NaCl}, 0.2 \%$ sodium dodecylsulfate, $10 \mathrm{~mm}$ EDTA, phenol/chloroform-extracted, and ethanol-precipitated. The DNA samples were resuspended in denaturing buffer $(10 \mathrm{mM} \mathrm{NaOH}, 80 \%$ formamide, $0.1 \%$ xylene cyanole, $0.1 \%$ bromophenol blue), heated for $2 \mathrm{~min}$ at $90^{\circ} \mathrm{C}$, electrophoresed in an $8 \%$ polyacrylamide $-7 \mathrm{M}$ urea sequencing gel, and visualized by autoradiography. In the competition experiments, extracts were incubated for $5 \mathrm{~min}$ with $200 \mathrm{ng}$ of the double-stranded oligonucleotides before adding the labeled probes.

\section{Gel retardation analysis}

Binding reactions were performed by incubation of radiolabeled fragments with 6-12 $\mu \mathrm{g}$ of nuclear extracts using the same conditions as described above. After the 30 -min incubation on ice, samples were layered onto low-ionic strength $5 \%$ polyacrylamide gels (acrylamide/bis-acrylamide weight ratio, $30: 1$ ) in TBE buffer [ $25 \mathrm{~mm}$ Tris $(\mathrm{pH} 8.0), 25 \mathrm{mM} \mathrm{H}_{3} \mathrm{BO}_{3}, 1 \mathrm{~mm}$ EDTA]. Gels were electrophoresed at $25 \mathrm{~mA}$ for $1-2 \mathrm{hr}$ at $4^{\circ} \mathrm{C}$, transferred to Whatman $3 \mathrm{MM}$ filters, dried, and autoradiographed. For the competition experiments, 50-100 ng of double-stranded oligonucleotides were added to the binding reactions prior the addition of the nuclear extracts.

\section{Methylation interference analysis}

End-labeled probes were methylated using dimethylsulfate for 3 min as described by Maxam and Gilbert (1980) and precipitated twice with ethanol in the presence of carrier DNA. The modified DNAs were incubated with nuclear extracts and electrophoresed as above. Wet gels were exposed overnight at $4^{\circ} \mathrm{C}$ with an intensifying screen. The bands corresponding to the DNAprotein complexes and the free probes were excised from the gel and electroeluted into dialysis bags. Then samples were purified by phenol/chloroform extraction, ethanol precipitation, and passage on NACS-Prepac columns (BRL). The recovered DNA was resuspended in $10 \%$ piperidine, heated at $90^{\circ} \mathrm{C}$ for 30 min, frozen and lyophilized twice. Then samples were resuspended in denaturing buffer, heated at $90^{\circ} \mathrm{C}$ for 2 min, electrophoresed in an $8 \%$ polyacrylamide $-7 \mathrm{M}$ urea sequencing gel, and visualized by autoradiography.

\section{Acknowledgments}

This work was supported by grants from the National Institutes of Health and the American Cancer Society. G.C. is the recipient of an Irma T. Hirschl Career Scientist Award.

\section{References}

Barberis, A., G. Superti-Furga, and M. Busslinger. 1987. Mutually exclusive interaction of the CCAAT-binding factor and of a displacement protein with overlapping sequences of a histone gene promoter. Cell 50: 347-359.

Biggin, M.D. and R. Tjian. 1988. Transcription factors that activate the Ultrabithorax promoter in developmentally staged extracts. Cell 53: 699-711.

Bryan, P.N., J. Olah, and M.L. Birnstiel. 1983. Major changes in the $5^{\prime}$ and $3^{\prime}$ chromatin structure of sea urchin histone genes accompany their activation and inactivation in development. Cell 33: 843-848.

Childs, G., R. Maxson, and L.H. Kedes. 1979. Histone gene expression during sea urchin embryogenesis: Isolation and characterization of early and late messenger RNAs of Strongylocentrotus purpuratus by gene-specific hybridization and template activity. Dev. Biol. 73: 153-173.

Childs, G., C. Nocente-McGrath, T. Lieber, C. Holt, and J. Knowles. 1982. Sea urchin (L. pictus) late stage $\mathrm{H} 3$ and $\mathrm{H} 4$ genes: Characterization and mapping of a clustered but nontandemly linked multigene family. Cell 31: 383-393.

Chodosh, L., A.S. Baldwin, R.W. Carthew, and P.A. Sharp. 1988. Human CCAAT-binding proteins have heterologous subunits. Cell 53: 11-24.

Colin, A.M. 1986. Rapid repetitive microinjection. Methods Cell Biol. 27: 395-406.

Colin, A.M., T.L. Catlin, S.H. Kidson, and R. Maxson. 1988. Closed linked early and late $\mathrm{H} 2 \mathrm{~b}$ histone genes are differentially expressed after microinjection into sea urchin zygotes. Proc. Natl. Acad. Sci. 85: 507-510.

Dale, R.M.K., B.A. McClure, and J.P. Houchins. 1985. A rapid single-stranded cloning strategy for producing a sequential series of overlapping clones for use in DNA sequencing: Applications to sequencing the corn mitochondrial $18 \mathrm{~S}$ rDNA. Plasmid 13: 31 - 40 .

Davidson, E.H., C.N. Flytzanis, J.J. Lee, S.J. Rose, and H.M. Sucov. 1985. Lineage-specific gene expression in the sea urchin embryo. Cold Spring Harbor Symp. Quant. Biol. 50: $321-328$.

Davidson, E.H. 1986. Gene activity in early development. Third edition. Academic Press, Orlando, Florida.

Flamant, F., C.C. Gurin, and J.A. Sorge. 1987. An embryonic DNA-binding protein specific for the promoter of the retrovirus long terminal repeat. Mol. Cell. Biol. 7: 3548-3553.

Flytzanis, C.N., R.J. Britten, and E.H. Davidson. 1987. Ontogenic activation of a fusion gene introduced into sea urchin eggs. Proc. Natl. Acad. Sci. 84: 151-155.

Fried, M. and D.M. Crothers. 1981. Equilibria and kinetics of lac repressor-operator interactions by polyacrylamide gel electrophoresis. Nucleic Acids Res. 9: 6505-6525.

Galas, D. and A. Schmitz. 1978. DNase I footprinting: A simple method for the detection of protein-DNA specificity. Nucleic Acids Res. 5: 3157-3170.

Garner, M.M. and A. Rezvin. 1981. A gel electrophoresis method for quantifying the binding of proteins to specific DNA regions: Application to components of the Escherichia coli lactose operon regulatory system. Nucleic Acids Res. 9: 3047-3060.

Gorman, C.M., L.F. Moffat, and B.H. Howard. 1982. Recombinant genomes which express chloramphenicol acetyltransferase in mammalian cells. Mol. Cell. Biol. 2: 1044-1051.

Heberlein, U. and R. Tjian. 1988. Temporal pattern of alcohol dehydrogenase gene transcription reproduced by Drosophila stage-specific embryonic extracts. Nature 331: 410-415.

Hentschel, C. and M.L. Birnstiel. 1981. The organization and expression of histone gene families. Cell 25: 301-313.

Hough-Evans, B.R., R.R. Franks, R.A. Cameron, R.J. Britten, and E.H. Davidson. 1987. Correct cell-type-specific expres- 
sion of a fusion gene injected into sea urchin eggs. Dev. Biol. 121: $576-579$.

Johnson, P.F., W.H. Landschulz, B.J. Graves, and S.L. McKnight. 1987. Identification of a rat liver nuclear protein that binds to the enhancer core element of three animal viruses. Genes Dev, 1: 133-146.

Katula, K.S., B.R. Hough-Evans, R.J. Britten, and E. Davidson. 1987. Ontogenic expression of a CyI actin fusion gene injected into sea urchin eggs. Development 101: 437-447.

Kaumeyer, J.F. and E.S. Weinberg. 1986. Sequence, organization, and expression of late embryonic $\mathrm{H} 3$ and $\mathrm{H} 4$ histone genes from the sea urchin, Strongylocentrotus purpuratus. Nucleic Acids Res. 14: 4556-4576.

Kemler, I. and M. Busslinger. 1986. Characterization of two nonallelic pairs of late histone $\mathrm{H} 2 \mathrm{~A}$ and $\mathrm{H} 2 \mathrm{~B}$ genes of the sea urchin: Differential regulation in the embryo and tissuespecific expression in the adult. Mol. Cell. Biol. 6: 37463756.

Knowles, J.A. and G. Childs. 1984. Temporal expression of late histone messenger RNA in the sea urchin Lytechinus pictus. Proc. Natl. Acad. Sci. 81: 2411-2415.

1986. Comparison of the late H1 histone genes of the sea urchins Lytechinus pictus and Strongylocentrotus pur. puratus. Nucleic Acids Res. 14: 8121-8133.

Knowles, J.A., Z. Lai, and G. Childs. 1987. Isolation, characterization, and expression of the gene encoding late histone subtype Hl-gamma of the sea urchin Strongylocentrotus purpuratus. Mol. Cell. Biol. 7: 478-485.

Lai, Z.C., R. Maxson, and G. Childs. 1988. Both basal and ontogenic promoter elements affect the timing and level of expression of a sea urchin $\mathrm{H} 1$ gene during early embryogenesis. Genes Dev. 2: 173-183.

Lai, Z.C. and G. Childs. 1988. Characterization of the structure and transcriptional patterns of the gene encoding the late histone subtype H1- $\beta$ of the sea urchin Strongylocentrotus purpuratus. Mol. Cell. Biol. 8: 1842-1844.

Lai, Z.C., D.J. DeAngelo, M. DiLiberto, and G. Childs. 1989. An embryonic enhancer determines the temporal activation of a sea urchin late $\mathrm{Hl}$ gene. Mol. Cell. Biol. 9: (in press).

Lieber, T., K. Weisser, and G. Childs. 1986. Analysis of histone gene expression in adult tissues of the sea urchins Strongylocentrotus purpuratus and Lytechinus pictus: Tissue-specific expression of sperm histone genes. Mol. Cell. Biol. 6: $2602-2612$.

Maniatis, T., E.F. Fritsch, and J. Sambrook. 1982. Molecular cloning: A laboratory manual. Cold Spring Harbor Laboratory, Cold Spring Harbor, New York.

Mauron, A., L. Kedes, B.R. Hough-Evans, and E. Davidson. 1982. Accumulation of individual histone mRNAs during embryogenesis of the sea urchin Strongylocentrotus purpuratus. Dev. Biol. 94: 425-434.

Maxam, A. and W. Gilbert. 1980. Sequencing end-labeled DNA with base-specific cleavage. Methods Enzymol. 65: 499560.

Maxson, R.E. and F.H. Wilt. 1981. The rate of synthesis of histone mRNA during development of sea urchin embryos. Dev. Biol. 83: 380-386.

1982. Accumulation of the early histone messenger RNAs during the development of Strongylocentrotus purpuratus. Dev. Biol. 94: 435-440.

Maxson, R.E., T.J. Mohon, R. Cohn, and L. Kedes. 1983a. Expression and organization of histone genes. Annu. Rev. Genet. 17: 239-277.

Maxson, R.E., T.J. Mohon, G. Gormezano, G. Childs, and L.H. Kedes. 1983b. Distinct organizations and patterns of expres- sion of early and late gene sets in the sea urchin. Nature 301: $120-125$.

McKnight, S. and R. Tiian. 1986. Transcriptional selectivity of viral genes in mammalian cells. Cell 46: 795-805.

McMahon, A.P., T.J. Novak, R.J. Britten, and E.H. Davidson. 1984. Inducible expression of a cloned heat shock fusion gene in sea urchin embryos. Proc. Natl. Acad. Sci. 81: $7490-7494$.

McMahon, A.P., C.N. Flytzanis, B.R. Hough-Evans, K.S. Katula, R.J. Britten, and E.H. Davidson. 1985. Introduction of cloned DNA into sea urchin egg cytoplasm: Replication and persistence during embryogenesis. Dev. Biol. 108: 420-430.

Melton, D.A., P.A. Krieg, M.R. Rebagliati, T. Maniatis, K. Zinn, and M.R. Green. 1984. Efficient in vitro synthesis of biologically active RNA and RNA probes from plasmids containing a bacteriophage Sp6 promoter. Nucleic Acids Res. 12: 7034-7056.

Messing, J. and J. Vieira. 1982. A new pair of M13 vectors for selecting either DNA strand of double digest restriction fragments. Gene 19: 269-276.

Mitchell, P., C. Wang, and R. Tjian. 1987. Positive and negative regulation of transcription in vitro: Enhancer binding protein AP-2 is inhibited by T-antigen. Cell 50: 847-861.

Morris, G.F., D.H. Price, and W.F. Marzluff. 1986. Synthesis of Ul RNA in a DNA-dependent system from sea urchin embryos. Proc. Natl. Acad. Sci. 83: 1-5.

Saiki, R.K., S. Scharf, F.A. Faloona, K.B. Mullis, G.T. Horn, H.A. Erlich, and N. Arnheim. 1988. Enzymatic amplification of $\beta$-globin genomic sequences and restriction analysis for diagnosis of sickle cell anemia. Science 239: 487-491.

Sanger, F., S. Nicklen, and A.R. Coulson. 1977. DNA sequencing with chain terminating inhibitors. Proc. Natl. Acad. Sci. 74: 5463-5467.

Santoro, C., N. Mermod, P.C. Andrews, and R. Tjian. 1988. A family of human CCAAT-box binding proteins active in transcription and DNA replication: Cloning and expression of multiple cDNAs. Nature 334: 218-224.

Sures, I., J. Lowry, and H. Kedes. 1978. The DNA sequence of sea urchin (S. purpuratus) H2A, H2B, and H3 histone coding and spacer regions. Cell 15: 1033-1044.

Vitelli, L., I. Kemler, B. Lauber, M. Birnstiel, and M. Busslinger. 1988. Developmental regulation of microinjected histone genes in sea urchin embryos. Dev. Biol. 127: 54-63.

Weinberg, E.S., M.B. Hendricks, K. Hemminki, P.E. Kuwabra, and L.A. Farrelly. 1983. Timing and rates of synthesis of early histone mRNA in the embryo of Strongylocentrotus purpuratus. Dev. Biol. 98: 117-129.

Wu, T.C. and R.T. Simpson. 1985. Transient alterations of the chromatin structure of sea urchin early histone genes during embryogenesis. Nucleic Acids Res. 13: 6185-6203. 


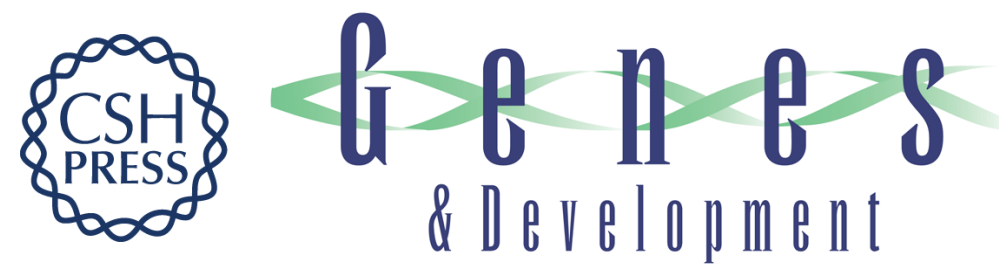

\section{Developmental control of promoter-specific factors responsible for the embryonic activation and inactivation of the sea urchin early histone $\mathrm{H} 3$ gene.}

M DiLiberto, Z C Lai, H Fei, et al.

Genes Dev. 1989, 3:

Access the most recent version at doi:10.1101/gad.3.7.973

References This article cites 49 articles, 17 of which can be accessed free at: http://genesdev.cshlp.org/content/3/7/973.full.html\#ref-list-1

License

Email Alerting Service

Receive free email alerts when new articles cite this article - sign up in the box at the top right corner of the article or click here.

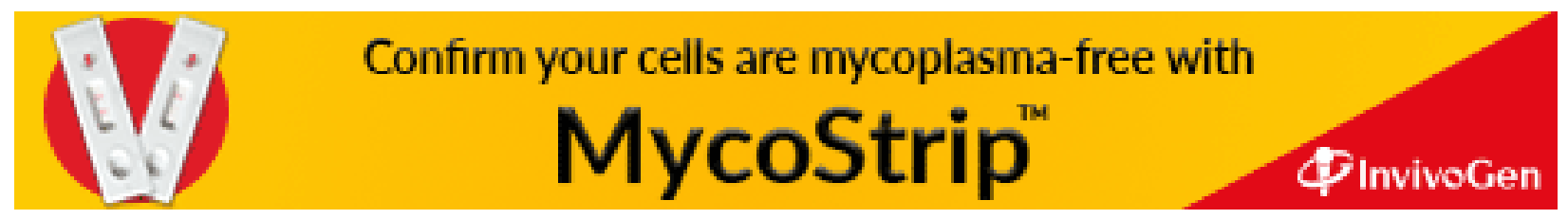

